Lebedeva, G.N. (2020). On the borders of Slavic identity: the search for self-determination and comparative analysis. Historical values and problems of their interpretation. Collection of Scientific Articles. European Scientific e-Journal, 5 (5), 39-51. Hlučín-Bobrovníky: "Anisiia Tomanek" OSVČ.

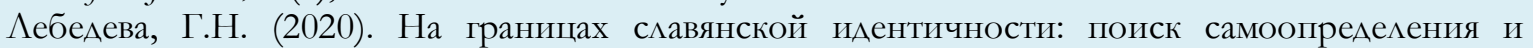
сравнительный анализ. Historical values and problems of their interpretation. Collection of Scientific Articles. European Scientific e-Journal, 5 (5), 39-51. Hlučín-Bobrovníky: “Anisiia Tomanek” OSVČ.

DOI: $10.47451 /$ his2020-12-003

EOI: $10.11244 /$ his $2020-12-003$

The paper is published in Crossref, Internet Archive, Google Scholar, Academic Resource Index ResearchBib, JGate, ISI, CiteFactor, ICI, eLibrary databases.

Galina N. Lebedeva Candidate of Philosophical Sciences (PhD)

Associate Professor Department of Philosophy Leningrad State University

St Petersburg, Russia

E-mail: gal_le@list.ru

ORCID: 0000-0002-6217-9929

\title{
On the borders of Slavic identity: the search for self-determination and comparative analysis
}

\section{Abstract:}

Language as a collective memory of the people, the historical past of the language is the embodiment of the spirit of the people; this is what was common to Russian and Czech figures in the first half of the 19th century. The names and biographies of outstanding scientists, who have made a great contribution to the science of their country, their abilities are not only history but also scientific information, concepts and the search for new knowledge. The article is devoted to the development of scientific organizations of the Slavic peoples. The nation is constantly changing, and each historical epoch corresponds to its idea of the nation. By the end of the 18th century, the southern and Western Slavic peoples had been under the foreign yoke for several centuries. As a result of active activity, Slavic literary languages, scientific and cultural organizations emerged.

Keywords:

science, Russian Academy, Dictionary of the Russian Academy, Slavs, E.R. Dashkova, A.S. Shishkov, Slovenian language, buditeli, Y. Dobrovsky, V. Hanka, P.Y. Šafařík.

\section{Аебедева Галина Никомаевна}

к. филос. н., Аоцент кафелры кафедра философии

Аенинградский государственный университет имени А.С. Пушкина

Санкт-Петербург, Россия

E-mail: gal_le@list.ru 
ORCID: 0000-0002-6217-9929

\section{На границах славянской идентичности: поиск самоопределения и сравнитемьный анализ}

\section{Аннотачия:}

Язык как колмективная память народа, историческое прошлое языка является воплощением Ауха народа; это то, что было общим Аля русских и чешских деятелей в первой половине XIX века. Имена и биографии вылающихся учёных, внесших большой вклаА в науку своей страны, их способности - это не только история, но и научная информация, концепции и поиск новых знаний. Статья посвящена развитию научных организаций славянских народов. Нация постоянно меняется, и каждой исторической эпохе соответствует своё представление о нации. Южные и западные славянские народы к концу XVIII века уже несколько веков находились под чужеземным игом. В результате активной деятельности возникали славянские Аитературные языки, научные и культурные организации.

\section{Kлючевые слова:}

наука, Российская Академия, Словарь Академии Российской славяне, Е.Р. Аашкова, А.С. Шишков, «словенский» язык, будители, Й. Аобровский, В. Ганка, П.Й. Шафарик.

\section{Introduction}

Language as a collective memory of the people, the historical past of the language is the embodiment of the spirit of the people; this is what was common to Russian and Czech figures in the first half of the 19th century. The names and biographies of outstanding scientists, who have made a great contribution to the science of their country, their abilities are not only history but also scientific information, concepts and the search for new knowledge. As information begins to be brought into the system, scientific organizations and academies appear. Such a system is very fragile, and it requires conditions that make it possible to create this new knowledge.

It should note the third factor: for the existence of science, initiative organizers, who independently, as well as in a long routine work with officials, authorities and bureaucracy, would be able to organize science and its institutions, are needed. Finally, as a sufficient amount of knowledge is accumulated, it becomes an element of school and university education, as well as becoming part of the culture of society.

As a result, science becomes an independent field of activity and is formed into an independent public institution. This is a complex way to obtain and preserve knowledge: from initiative individuals to building a system. This article takes an 
example of how the process of organizing science has gone from public and private hobbies to the formation of special institutions.

There is no clear answer to the question of the origin and essence of the nation, as well as national identity, cultural identity. The most recent and complex type of ethnic group is the nation. There is no single scientific definition of a nation, and literature is so very diverse. In addition, the nation is not something unchangeable. The urban upper classes and aristocracy were foreign (except for the poles), and the Slavic population consisted of the lower strata (the peasantry and the urban lower classes). The Slavs were only peasant societies, divided socially and religiously. Breaking the class partitions, the national intelligentsia and science began to form.

\section{Creation of the Russian Academy}

In Russia in the second half of the 18th century, this role was assumed by women. Ekaterina Romanovna Dashkova (1743-1810) was not only a friend of Catherine the great, but also had a direct relationship to the formation of public associations, science, philology, and philosophy in Russia. After spending 8 years (from 1869 to 1771, and from 1776 to 1782) traveling in Europe, she was familiar with kings, scientists, and artists: from educators (Diderot, Voltaire) and scientists (economist A. Smith, historians (W. Robertson and A. Ferguson) to bankers and the Pope, with whom she discussed the Vatican Museum being created. In 1779, on the way back to Russia, she was at a reception with the French queen in Paris. She attended scientific meetings, participated in debates, and even wrote music.

E.R. Dashkova resumed cooperation with Catherine the Great in 1782, and on January 24, 1783, a decree was issued on the appointment of E.R. Dashkova as director of the St. Petersburg Imperial Academy of Sciences, and she headed the established Russian Academy from October. The Empress sought to achieve political goals: the national language, brought to certain norms, was an attribute of the state, and the existence of a dictionary of the national language was evidence of the high culture of society. The Italian Academy of Crusca in Florence, the Spanish Royal Academy, and especially the French Academy, known for their dictionaries and grammars, served as an attractive example (Kopelevich \& Ozhigova, 1989), e.g., in France, in 1635, a decree of Richelieu established the French Academy, "to make the French language not only elegant, but also capable of interpreting all the Sciences and arts". Given the success that followed in spreading the French language in America, Africa, and France, a similar decision was also made in England. In 1662, The Royal Charter approved the creation of the Royal Society of London (an analogue of the Academy of Sciences) with the aim of the same expansion of the English language in the 
conquered territories in the United States, Canada, Australia, Africa and Russia. The expansion of language capabilities, the special desire to direct the language of science in an academic way, were considered as the basis of national security for each country. "The creation of such an Academy demonstrated the importance of language culture. It was about the prerequisites for the preparation of the cultural elite of the Empire." (Feinstein, 2002) The establishment of the Academy further contributed to the better implementation of the reform of public education.

Already in 1783, Dashkova prepared for publication the first academic collection of works by M.V. Lomonosov The Complete Works of Mikhail Vasilyevich Lomonosov, with the Introduction of the Life of the Composer and the Addition of Many of His Works not yet Printed Anywhere, published in 6 parts in St Petersburg in 1784-1787. A.A. Nartov developed translation activities. By the time of the 1810s, the result of this period was that educated Russia used the norms of the Russian language defined by the Dictionary of the Russian Academy. After the resignation of Dashkova, several presidents had been replaced, when A.S. Shishkov became the President in 1813. He recalled the circumstances, "I told the Emperor whether it would be desirable for him to entrust the Academy to me, saying that I was not asking for this for any of my benefits, but only out of zeal and love for the Russian language and literature." (Shishkov, 1870)

In his long career, A.S. Shishkov believed that the Russian Academy was created to strengthen and protect the Slavic-Russian language and from the penetration of French and English languages and religions into it. The last 28 years of the Academy's work were associated with his name, until the accession of the Russian Academy to the Academy of Sciences as the second department (Department of Russian language and literature, ORYAS). Alexander Semyonovich Shishkov (09.03.1754-09.04.1841), writer, literary critic, philologist, admiral, active participant in the events of his time, later state secretary, minister of public education, and the president of the Russian Literary Academy. He was born into a poor family of small-scale, as he wrote, "sufficient" nobility. At the age of 10, he was sent to the naval cadet corps in St Petersburg, from which he graduated with the rank of Midshipman in 1772. He made a three-year journey, during which visited Italy, Greece and Turkey. Literary fame was brought to him by the play Slavery (1780), which was based on a description of a real case: the fate of a Russian sailor who fell into slavery to Algerian pirates. The production of the play was attended by the Empress and her heir Pavel Petrovich, who donated significant sums for the ransom of the person in trouble. After the success of the play, Shishkov began to enter literary salons (The works of the society of lovers of Russian literature, 1812). Shishkov's literary studies were interspersed 
with participation in military campaigns. Some time later, in 1793, he translated Naval Tactics from the French. In his collection of translations, Tasso's Vigils and Jerusalem Liberated, Petrarch's sonnets can be found. At the same time, Alexander Semyonovich translated I.G. Kampe's Children's Library from German. This translation made Shishkov a favorite children's writer in Russia for a long time, until the middle of the 19th century. By order of the director of the St Petersburg Academy of Sciences E.R. Dashkova, this book was printed in the academic printing house (Kampe, 17831785).

In 1796, A.S. Shishkov was elected a member, and from 1813 - President of the Russian Academy, which he headed until the last days of his life. Since then, he has been completely immersed in the study of the Russian language and history. Since 1805, the Russian Academy, on the initiative of A.S. Shishkov, has published Works and Translations, in which he puts his original and translated articles, his translation of Words about Igor's Regiment and extensive notes that explained the meaning of obscure and ancient words. In 1803, A.S. Shishkov published his work Reasoning about the Old and New Syllable of the Russian Language. The publication of the work was marked by contemporaries as the beginning of the struggle between two literary trends in the development of the literary language, whose supporters were called "karamzinists" and "shishkovists". Minister of Public Education and chief administrator of Spiritual Affairs of Foreign Confessions (from 1824 to 1828).

\section{Language as a collective memory of the people, the historical past of the language - the embodiment of the spirit of the people}

In addition, Shishkov developed a plan to create an all-Slavic scientific center in Russia. He had a special idea of the people, a special cult of the people: the people were preserved in the language, its guarantor was the ancient Russian literature. In turn, if we abandon the national principles, it would mean the exclusion of the nation from the enlightened peoples.

The first thing he did was to draft a new Charter for the Academy, which was approved after some discussion on May 29, 1818. Shishkov, setting out the reasons for the need for a new charter, wrote that the Academy was designed to be "the guardian of the language from all bad skills that can damage and shake it, unfair interpretations and abuses introduced into it". It was planned to continue working on various dictionaries: a dictionary of the Russian language, a comparative dictionary of all Slavic dialects, dictionaries of technical and verbal sciences, and Slavic scientists had to work in their creation. In the first third of the 19th century, more and more attention was paid to the commonality of Slavic languages. The 
directions of work on the dictionary were outlined - etymological and alphabetic. The first one, etymological, was supervised by the president himself. Subsequently, this method has received the name "wordrootology", i.e., the science of word roots.

The strongest contacts were established with Slavic scientists even under Dashkova. The first Slavic correspondent A.A. Baričevič (Baryševič), a gymnasium teacher, member of the Turin and Neapolitan academies, author of studies on the history and literature of Croatia. In 1784, during the reign of E.R. Dashkova, his books came to St Petersburg from Agram (now Zagreb).

By the beginning of the 19th century, foreign Slavs had been under foreign rule for several centuries, and only Montenegro had full independence from the Slavic lands outside of Russia. The rest of the peoples lived under the rule of the Germans and Hungarians (in Austria-Hungary) and the Turks. This did not help the Slavs to be interested in their identity, and even more so to pay attention to freedom in the national question. In addition to political and social, most foreign Slavs also experienced cultural humiliation. Their languages were reduced to the level of vernacular dialects, there were prohibitions on teaching in their native language. In the Ottoman Empire, religious oppression was added to this. Even at the beginning of the 19th century, assimilation and dissolution in the surrounding peoples of the Slavs seemed a matter of time. Most of the citizens of the Czech Republic and Slovenia spoke German, in the few cities of Slovakia and Croatia the Hungarian language prevailed, and Italian was practised among the inhabitants of the ancient cities of the Dalmatian coast. However, even among the Slavs who preserved their language and self-consciousness, disturbing processes took place. Among the Austrian Slavs, a noticeable layer began to make up various groups that switched to German language and culture, although they considered themselves Czechs, Slovenes and Croats. It was no coincidence that the famous Czech historian and philosopher J. Dobrovsky (1753-1829) considered the history of his people complete and wrote his books in German. He also published the first grammar of the Czech language, but in German.

A striking phenomenon of the era was the revival of the almost disappeared Slavs of Europe. In the Eastern Europe, this was manifested, first of all, in the cultural and ideological sphere, in public thought, in the views of advanced thinkers, writers, who in some countries bore the proud name of 'awakeners', or 'buditelé' in Czech. The Slavic peoples did not have their aristocracy (except for the poles, but they had a very large one), they did not have their bourgeoisie, to a certain extent even the middle urban strata (almost completely assimilated), artisans and the working class were absent. In principle, the Slavs were only peasant societies, divided 
both socially and religiously. Most of the educated people in the Austrian Empire came from the lower strata of society. Breaking the class partitions, the national ideology began to form. It was simple: the Slavs must be preserved as a community.

\section{Example of the Czech people}

It should be looked at the example of the Czech people, who had the most successful conditions in comparison with other Slavic peoples. The rise of national culture was favored by a background from the past: literary and cultural tradition, features of urban culture, and what is especially important-the existence of a network of lower (elementary) schools that used their native language, as well as secondary and higher schools. At the same time, in the Czech Republic, since the Thirty Years' War, there was no own nobility, unlike other Slavs, who did not have their aristocracy and remained, in fact, peasant peoples. This was accompanied by political circumstances: The Czech Republic (Bohemia) in the Habsburg Empire had a certain territorial self-government, existing as a Kingdom, having the monarch of the Austrian Emperor. Thus, for the Czech rulers, the main thing at the beginning of the 19th century was not the struggle for independence, but the prevention of final Germanization.

The national revival began with the formation of national literary languages, with the struggle for the rights of the native language, its preservation and application in various social and cultural spheres. And it is impossible not to be struck by the fact that Czech, Slovak, and Slovenian, which have almost disappeared as spoken languages, have acquired a literary form and have really become the language of the people. The idea of Slavic solidarity began to spread rapidly, first becoming a form of national consciousness, and then the ideology of the Renaissance. Many European scientists (J.G. Herder, J. Dobrovsky, J. Jungman, J.B. Kopitar) were convinced that the Slavs are a single people.

In order not to talk about the national revival "in general", as an example, it should be cited the activities of two outstanding Czech 'awakeners', as they called the figures who awakened the Czech people.

The first is the name of the founder of the grammar of the Czech language. This is Josef Dobrowski (born 1753), who was not only the "Patriarch of the Czech national revival", but also ahead of his time. J. Dobrovsky was imbued with faith in the great destiny of the Slavs in the history of mankind. In 1792-1793, he made a trip to St. Petersburg and Moscow. Without the Moscow experience (Dobrovsky studied ancient Slavic manuscripts there), there would not have been a book Instructions on the Language of Ancient Slavic Dialects. The monuments of old Slavonic writing from 
Russian book repositories were rich material for his work. Dobrovsky's book aroused great interest and sympathy in the Czech Republic for Russia and the Russians. In turn, he was well known and appreciated in Russia. He was a member of the Russian Academy of Sciences; he is rightly considered the founder of Slavic and Bohemian studies (Frantsev, 1923).

A.S. Shishkov wanted to get acquainted with J. Dobrovsky very much. In 1809, he received the first volume of Works and Translations Published by the Academy (St Petersburg, 1805) and the first volume of the alphabet dictionary from Shishkov. They met in Prague in 1813. In 1822, the last, 6th volume of the second alphabet Dictionary of the Russian Academy was published. After studying it, I. Dobrovsky responded with a review. He emphasized the great role of the Academy's members: "The Russian Imperial Academy, founded in 1783, thanks to the Russian dictionary, its first brainchild, has set itself a glorious, enduring monument. All the members of the Academy had to contribute to this work, and the publication of the dictionary was issued with a speed that does credit to the zeal of the members of the Academy." J. Dobrovsky approved the arrangement of words according to the alphabet principle, and considered the lack of old Russian words to be a disadvantage. He wrote that "a special advantage would have been given to this work if it were enlarged by all the Slavic words that occur in Nestor and other chroniclers". This remark pleased A.S. Shishkov, who sought to cover the language of the origins, and in the person of J. Dobrovsky found a faithful ally in the desire to cover the vocabulary of the "Slovenian" language.

In 1820, A.S. Shishkov wrote to J. Dobrovsky about the election of him and J. Nejedlý to honorary members of the Academy, and sent books. Together with the diploma of an honorary member, 49 books were sent to J. Dobrovsky. The Charter of the Academy of 1818 stipulated that "it is necessary for the Academy to communicate with many Slavic dialects by professors, bookkeepers and other learned people", who could also be elected foreign honorary members of the Academy (The collections of works and translations of Admiral A.S. Shishkov, 1818). 6 people were elected. Three of them are Slavic scientists: S.B. Linde, J. Dobrovsky, J. Nejedlý.

The idea of a comparative Slavic dictionary began to be implemented, and the need for constant contacts with scientists was also emphasized. It is known that scientists V. Hanka, F.L. Čelakovský, P.J. Šafař́k, I.A. Jungmann, J. Kollar sent their grammar books and dictionaries to St Petersburg. So, a lot of material was accumulated for future work on the Dictionary. For 30 years, the Academy has been working on a plan to create a general Slavic comparative dictionary. Another correspondent of the Academy was V. Kopitar, who sent some of his works to St 
Petersburg, for which he was awarded a silver medal and cash prizes. Feedback was also established: on the recommendation of N.P. Rumyantsev, P.I. Köppen made a trip to the Slavic lands in 1821-1824. Relations were established with the younger generation of awakeners. Acquaintance with V. Hanka, J. Dobrovsky, F. Palatsky, J. Kollar, F.L. Čelakovský, V. Kopitar, V. Karadzic led to continuing contacts. Then the Academy decides to invite some Slavic scientists from Austria.

Other Czech figures also played an important role in the revival of Slavic literatures and peoples. Pavel Josef Šafaŕk (1795-1861) was at the same time Slovak and Czech Slavist, poet, figure of national revival. He played an outstanding role in the development of the Slavs. He was born in the family of a teacher and an Evangelical priest, and in 1817, he graduated from the University of Jena, where he was a brilliant student, and the University awarded him the degree of doctor of philosophy without protection. During the same period, he became imbued with the ideas of Slavic revival and Slavic reciprocity. In 1819-1833, Šafař́k was a teacher and director at the Serbian Orthodox gymnasium in Novi Sad. At the same time, his first significant work History of Slavic Languages and Literatures in All Dialects was published in 1826. In 1823, a collection of Slovak folk songs "Písně světské lidu slovenského v Uhř́ch" was published in Pest.

His first major work was History of the Slavic Language and Literature in All Dialects, published in 1826 in German. This was the first generalizing work, which gave a characteristic of the languages and literatures of all Slavic peoples and it caused a wide response in Slavic studies of that time.

In 1833, P.J. Šafarílk moved to Prague, where he spent the rest of his life. In 1834-1835, Šafař́k was editor of the Světozor magazine, curator (1841) and director (1848) of the Prague University Library. Owever, he did not have a permanent reliable position. In general, he held a modest position of editor, and mostly lived on the salary of the censor.

One of the main works, on which he worked in Prague, was Slavic Antiquities ("Slovanské starožitnosti"; in 1837, the first, historical and geographical volume was published). This work is considered by many to be a scientific feat of P.J. Šafařik. He carefully analyzed all available sources about the origin and history of the ancient Slavs, he justified their Indo-European origin and also showed their contribution to world history and culture.

Slavic Antiquities was translated from Czech into Russian, German, Polish, and became an encyclopedia of Slavic studies for a long time and the basis for further study of the history of Slavic peoples. The first Russian Slavists Sreznevsky, Preis, 
Grigorovich, based on Šafařík's book, read their courses and used the materials in research activities.

The results of Šafařík's ethnographic works were reflected in the book "Slowanský národopis" (Slavic Ethnography) (Prague, 1842). Also, P.J. Šafař́k was engaged in the study of Glagolitic writing. In the last years of his life, he completely switched to studying the monuments of ancient Slavic writing. To solve the mystery of Glagolitic, he published several works on this topic. In 1858, he published his last work On the Origin and the Homeland of Glagolitsa. The Russian Academy awarded Šafařík a gold medal for his work, and scientific societies in Russia, Germany, Sweden, Serbia, and America elected him as a member. The scientist tragically died in Prague on June 26, 1861. He was buried in the Olshansky cemetery.

Of course, Šafařík was not alone in his activities. Václav Hanka (1791-1861) already knew many Slavic languages during his studies at Charles University. He created a circle for the defense of the Czech language. In 1813, he went to Vienna to study law. At the same time, he met J. Dobrovsky. Returning to Prague, he published the Description of Russia and its troops (1815, written based on information from Russian soldiers returning from the Napoleonic campaign home to Russia). V. Hanka was interested in the Slavic world, and in 1817, he translated Serbian songs into Czech. Seeking to awaken the nation, in 1817, he began publishing old Czech manuscripts of Ancient Tales, in 5 volumes, hoping that the new literature should be based on ancient monuments. In 1818, he opened and soon published the so-called Kraledvorskaya Manuscript, a collection of poems and songs of the 13th and 14th centuries.

In Russia, this work was immediately translated by A.S. Shishkov in St Petersburg and then A.I. Sokolov in Kazan and N.V. Berg in Moscow (1851).

V. Hanka kept in touch with many Russian scientists and corresponded with them, was elected a corresponding member of the Imperial Academy of Sciences and did much to popularize Russian culture, with which the Czechs were one-sidedly familiar. Hanka translated The Word about Igor's Regiment into Czech (1821).

His relations with Russia were active. He offered to strengthen the study of Slavs in Russia, for which he developed a plan for the establishment of Slavic departments in Russian universities. He was offered the position of librarian on good terms, but he refused to leave Prague. For his services in the field of literature and Slavic antiquities, Hanka received the order of Vladimir, the 4th class, from the Russian government, and in 1836 he also was awarded by the Russian Academy of Sciences a large gold medal. From 1848 until the end of his life, he taught old Slavonic and Russian languages at the Charles University. Hanka's reputation as a scientist was 
severely affected by the falsifications of historical monuments discovered after his death. Guided by the best intentions, he really embellished many historical information, created a whole list of fake historical chronicles. However, in our days, when almost all the historical data were composed in Ukraine, which still embellished the real history no longer seems to be something bad.

The interest in antiquities, the work and translation of the text of The Word about Igor's Regiment were what A.S. Shishkov, Y. Dobrovsky and Hanka did at the same time. Shishkov, heading the Ministry of National Education, decided to organize departments for the study of Slavic literature and history. His advisor was P.I. Köppen, a Slavist, bibliographer and statistician.

In February 1827, A.S. Shishkov, as Minister of Public Education, made a proposal to the Committee of the Organization of Educational Institutions on the need for special literature "uniform terminology, on the search and introduction of so-called technical terms existing in our language in educational books". Further, he convinced of the need to teach the Slovenian language in high schools, that every educated Russian was not only decent, but even should have had at least some idea of the division of the Slovenian language into different adverbs and the main properties of these (Frantsev, 1902). A.S. Shishkov had planned to create in Russia of the Department of Slavic Literatures and History and to bring Slavic scientists to this.

Problems about the invitation of Slavic scientists, the creation of a common dictionary occurred in difficult circumstances: in the ranks of the Decembrists there was the Society of United Slavs and the Tsar regarded it as a Jacobin infection. He was afraid of the national liberation movements of the Slavic peoples. In addition, in 1834, František Čelakovský issued a condemnation of Russian policy in Poland. Later, the Academy provided assistance to Matica: Serbian and Slovak. Books were sent to Presburg, and J. Kollar's Daughter of Glory book was purchased.

Not only Russian, but also Slavic scientists - Czech F. Čelakovský, Polish philologist S. Linde, Serb V. Karadzic - participated in the work on The General Slavic Etymological Dictionary. Historical research, which A.S. Shishkov encouraged to promote the strengthening of Russian statehood, was the forerunner of the Russian Slavophiles.

He attached special, not only scientific, but also socio-political importance to Slavistics as a means of satisfying foreign policy tasks, but he diverged from the supreme power in the perception of the problems of the Slavic world. He did not express the desire for expansion and seek to destabilize the European world, which Nicholas the First feared. Everthing that Shishkov sought, was only the cultural interpenetration of the Slavic peoples. The Academy had its foreign policy in the 
field of culture and science. The lack of understanding of this by the supreme power later became the reason for the closure of the Academy.

In 1835, the General Charter of the Imperial Russian Universities, according to which the departments of history and literature of Slavic dialects were established in St Petersburg, Moscow, Kharkiv and Kazan universities, i.e., the post of ProfessorSlavist was introduced, who was obliged to teach Slavic languages, literature and history of the southern and Western Slavs, was adopted. In this connection, the Ministry of Public Education decided to send four candidates for these positions (P.I. Preis, O.M. Bodyansky, I.I. Sreznevsky and V.I. Grigorovich) to the Slavic lands to study the languages, literatures, and ethnography of related tribes.

\section{Conclusion}

Scientific societies represent a historically formed form of scientific organization, well understood by their creators: "The observations and experiments, made on the emerging peoples, show that among all means to contribute to the universal success of education, the most convenient can be the establishment of Scientific Societies, which, being animated and guided by the creative spirit of the government, strive to act together to one noble goal" (The works of the society of lovers of Russian literature, 1812).

Attaching importance to the language of the people, A.S. Shishkov emphasized that "a learned language always requires some difference from the common language to acquire importance. He sometimes shortens, sometimes copulates, sometimes changes, sometimes chooses the word." (The collections of works and translations of Admiral A.S. Shishkov, 1818)

In conclusion, it should be noted that:

1. Shishkov showed by the experience of his biography and scientific activity that the administrator's organizational abilities do not prevent him from combining the authority of a statesman on a national scale, and also not to impose his opinion on the authorities.

2. Slavic peoples without barricades, parliamentary debates, beautiful phrases and spectacular gestures, thanks to such modest figures as J. Dobrovski, P.J. Šafařík and $\mathrm{V}$. Hanka were able to survive in this world as a nation. So, by the beginning of the revolution of 1848, the Slavs of the Austrian Empire had already developed literary languages. In the future, the Slavic idea became a means of preserving their culture and fighting for their rights. 
3. The idea that since ancient times the Slavic peoples had a Slavic identity along with an ethnic one, influenced the development of linguistics and science, as well as the emergence of the idea of Slavic reciprocity.

4. Having briefly considered the formation of the idea of Slavic reciprocity in the first half of the 19th century, it can be noted that although neither cultural nor political unification of the Slavs occurred, a single Slavic language did not develop, but this idea played a role in awakening the national consciousness of the Slavic peoples.

Thus, the processes of nation formation are closely connected with the national culture, the formation of cultural centers, the spread of education, the press, etc. At the time of the formation of a nation, the problem of language - its dissemination, the creation of norms of the national literary language - plays an important role. Therefore, the study of culture should be combined with lingue-social problems. If Slavic historians, literary critics, and linguists are already conducting comparative typological studies, since separate national histories and literary histories already exist and are sufficiently developed, and linguistic material has been accumulated, then this cannot be done concerning the history of culture.

\section{References:}

Agnew, H. (2004). The Czechs and the Lands of the Bohemian Crown. Hoover Institution Press.

Feinstein, M.S. (2002). "And the glory of France in Russia to exceed...” of the Russian Academy (1783-1841) and the development of the Humanities. St Petersburg

Frantsev, V.A. (1902). Essays on the bistory of the Czech Renaissance: Russian-Czech scientific relations of the end of the 18th and first half of the 19th centuries. Warsaw: The Publishing House of Warsaw Academic District.

Frantsev, V.A. (1923). The journey of Dobrovskiy and count J. Sternberg to Russia in 1792 93. Prague. (in Czech)

Kampe, I.G. (1783-1785). Children's library. Translated from German by A.S. Shishkov. St Petersburg: Dependent Imperial Academy of Sciences.

Kopelevich, Y.H. \& Ozhigova, E.P. (1989). Academies of science of the countries of Western Europe and North America. Leningrad.

Shishkov, A.S. (1870). Notes, opinions and correspondence of Admiral A.S. Shishkov: in 2 vols. Vol. 2. Berlin.

Sukhomlinov, M.I. (1887). History of the Russian Academy. Vol. 8. St Petersburg. 
The collections of works and translations of Admiral A.S. Shishkov. Part 3. (1818). St Petersburg.

The works of the society of lovers of Russian literature. Vol. 1. Books 1-2 (1812). Moscow. 